\title{
The Impact of Price and Non-Price Factors on Area Allocated to Oilseeds in India: An Application of ARDL Model
}

\author{
Debasis Mithiya $^{1}$, Simanti Bandyopadhyay ${ }^{2} \&$ Kumarjit Mandal $^{3}$ \\ ${ }^{1}$ Guest Professor of Economics, Department of Business Administration, International School of Hospitality \\ Management, Kolkata, India \\ ${ }^{2}$ Associate Professor of Economics, Department of Economics, Victoria Institution (College), University of Calcutta, \\ Kolkata, India \\ ${ }^{3}$ Associate Professor of Economics, Department of Economics, University of Calcutta, Kolkata, India
}

Correspondence: Debasis Mithiya, Guest Professor of Economics, Department of Business Administration, International School of Hospitality Management, Kolkata, India.

Received: May 13, 2021

doi:10.11114/aef.v8i4.5238
Accepted: July 28, $2021 \quad$ Available online: July 28, 2021

URL: https://doi.org/10.11114/aef.v8i4.5238

\begin{abstract}
The study attempts to investigate the dynamic relationship between acreage allocation of oilseeds and price (own price and prices of competitive crops) and also search for the link between area allocation and other non-price factors including productivity, irrigation, rainfall, technology and a policy-making variable (economic liberalization). The dynamic panel data for the year 1976-77 to 2017-18 have been used in the analysis. The study has used the autoregressive distributive lag (ARDL) model to understand the relationship between the dependent and the independent variables and to investigate the long-run equilibrium relationship between them. To estimate the model, both PMG (Pooled Mean Group) and MG (Mean group) estimation methods have been used. The Hausman test has been conducted to see the difference between the PMG and the MG results. The outcomes show that PMG serves as an efficient estimator here. The error correction terms are negative and significant. The results show strong evidence of area allocation towards oilseed crops, indicate a strong co-integration among their determinants in the long run. The ARDL results indicate that the speed of adjustment towards long-run equilibrium varies from 14.8 to 40.6 percent.
\end{abstract}

Keywords: auto regressive distributive lag model, co-integration, dynamic panel data, hausman test, mean group estimation, oilseeds, pooled mean group estimation

Gel Classification: C 22, C23, Q 10

\section{Introduction}

India is one of the largest producer and consumer of vegetable oils in the world. Oilseeds have been the backbone of the agricultural economy of India since long. The Indian vegetable oil economy is the fourth largest in the world right after the USA, China, and Brazil. The country contributes 7 percent of the global vegetable oil production with a 14 percent share in the area. Oilseeds account for 13 percent of the gross cropped area, 3 percent of the Gross National Product (GNP), and 10 percent value of all the agricultural commodities (Government of India, 2018a). Oilseed crops play an important role in the Indian agricultural economy, next to food grains, in terms of area and production. The Indian climate is suitable for the cultivation of oilseed crops; therefore, large varieties of oilseeds are cultivated here. The oilseeds cultivated in our country are groundnut, rapeseed-mustard, castor, sesame, niger, linseed, safflower, sunflower and soybean. Among these oilseeds castor and linseed are non-edible while others are edible. However, groundnut, rapeseed-mustard, sesame and soybean account for a major chunk of the output, i.e., 92.20 percent of total oilseeds and 98.34 percent of total edible oilseeds (TE 2017-18). During this period, 25.59 million hectares of land is under oilseeds cultivation and has produced 28.87 million tons of oilseeds.

The Government of India focused attention on oilseeds and pulses once self-sufficiency in food grains production was achieved through Green Revolution. The oilseeds sector was a cause of concern to the policymakers in the post-reform period as India had become one of the largest importers of edible oils in the world due to stagnation in production coupled with increasing demand for the same. India imported more than half of the domestic requirements during the 
1990s. While India, was a net exporter of oilseeds, oilcake and edible oils till the 1960s, the scenario changed by the late 1970s. During the mid-1980s, the volume of edible oils import was alarming. It was 30 percent of the total imports standing next to petroleum. The government decided to achieve self-sufficiency in edible oilseeds production by 1990s through various policies and technical support to this sector and towards that end, the Technology Mission on Oilseeds (TMO) was launched in May 1986 to increase oilseeds production. After TMO was adopted, oilseeds production changed dramatically and India became self-sufficient in oilseeds production by the early 1990s. After opening up the edible oil sector in 1994 as a part of economic reforms, the production of edible oilseeds suffered a lot and remained almost stagnant through the late 90s (Sharma, 2017). Currently, the domestic consumption of edible oils has increased substantially over the years and has touched the level of 24.23 million tons in 2018-19 and is likely to increase further with rising income and population growth. The growth in production of domestic edible oils (10.06 million tons in 2018-19) has not been able to keep pace with the growth in consumption and the gap between production and consumption is being met through imports (14.92 million tons in 2018-19). The cost of import of edible oil entails a huge drain on the exchequer and this has touched Rs. 95750 crore in 2016-17 (Government of India, 2014 \& Government of India, 2018b).

To improve the situation of oilseeds production in the country, the government of India has been pursuing several development programs like Oilseed Growers Cooperative Project, National Oilseed and Development Project, Technology Mission on Oilseeds (TMO) and Integrated Scheme on Oilseeds, Pulses, Oil Palm and Maize (ISOPOM), etc. But its productivity is still low as compared to other oilseed producing countries in the world. The low and fluctuating productivity is primarily because the cultivation of oilseed crops is mostly done on marginal lands, which are lacking in irrigation and low levels of inputs are used here (Kiran Yadav, 2011 )

Oilseeds cultivation is largely done in rain-fed areas (72 percent) with risk in investment. The annual growth rates of area ( 0.99 percent), production (3.00 percent) and yield (2.02 percent) of oilseed crops during 1999-2000 to 2015-16 have declined as compared to that of 1986-87 to 1998-99 (Area: 2.53 percent, Production: 5.26 percent and Yield: 2.73 percent).

\subsection{Statement of Problem}

The growth of the oilseeds sector and trade in oilseeds are of primary concern to the Indian policymakers. This sector became an oilseeds exporter and earned foreign exchange during the 1960s but has turned into a leading importer of the world since late 1970s. To regain the status of an exporter of oilseeds, the sector needs to provide a surplus over and above the requirements of the domestic population. In order to generate surplus in oilseeds production that facilitates export, the policymakers may resort to structural reforms in the oilseeds sector, like pricing policies in favour of oilseeds, the trade and exchange rate policies in favour of the sector, etc. Hence, the policymaker would require detailed knowledge of the supply response parameters of the oilseed crops.

The analysis of the growth of oilseeds production under different studies indicates that the growth of oilseeds production has been uneven across regions and over time. The factors favoring edible oilseeds production in some regions and the factors against it in other regions across different time periods need to be identified. The volume of output of an oilseed crops depends mainly on two factors, namely, the area under its cultivation and yield per unit of land. In Indian agriculture, the productivity of oilseeds has never achieved expected level. The increase in the production of oilseeds has fluctuated with changes in the area. So till date, the production of oilseeds depends mainly on the area. After economic reforms (opening up the edible oils sector), the area under major edible oilseeds (except Soybean) remained stagnant or declined. The sequence chart (Fig.1) of major edible oilseeds in India is shown below. 

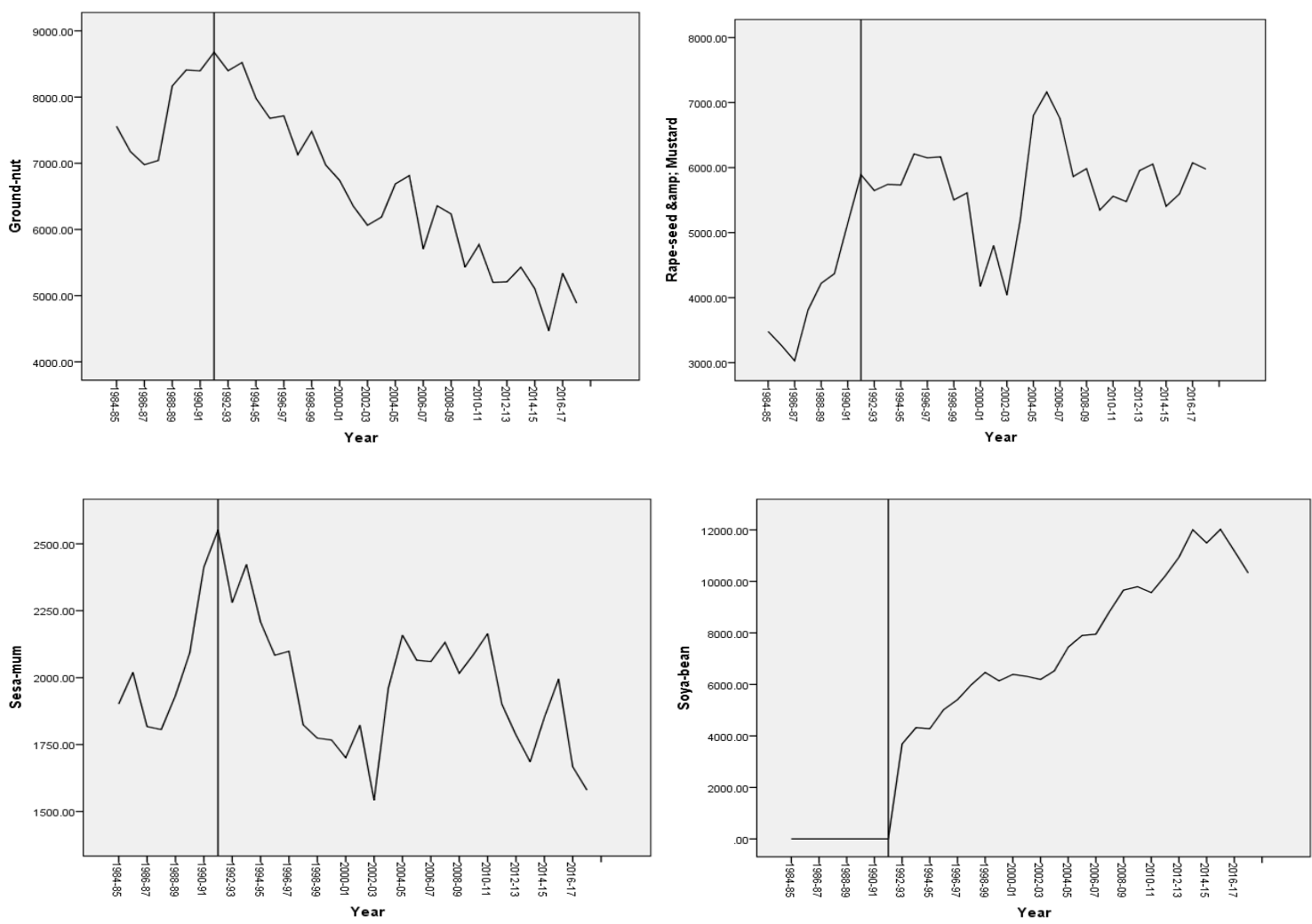

Figure 1. Trend of acreage allocation under Major Edible oilseeds

Economic liberalization led to a shift in acreage under food grains to acreage under non-food grains, especially high-value crops. Policy support was provided to encourage farmers to diversify their cropping pattern towards high-value crops. However, the land allocation decision of farmers depends on returns and risks associated with a particular crop vis-a-vis competitive crops. The other factors that influence area allocation decisions include the availability of inputs, irrigation, rainfall, technological support and price, etc. Therefore, keeping all these in mind, the focus of the present study will be to analyze the impact of both price and non- price factors on allocation of area for edible oilseeds. This is done because the growth of the production of edible oilseeds has largely been influenced by the growth of the area. The specific objectives of this study are listed below:

\subsection{Objectives}

- To estimate responsiveness of area allocation under major oilseed crops to price and non-price factors in India both in short and long term conditions. More specifically, the study attempts to determine the factors which favored or discouraged the allocation of the area under major oilseeds namely groundnut, rapeseed-mustard, sesame and soybean during the period 1976-77 to 2017-18.

- To find the impact of TMO and liberalization (New economic policy) on the allocation of area under these oilseeds.

\section{Study Area and Data Source}

\subsection{Study Area}

The oilseed crops have been chosen in terms of their proportional contribution in total edible oilseeds output as well as the percentage of area under cultivation. Groundnut, rapeseed-mustard, soybean, and sesame account for a major chunk of the output i.e., 98.34 percent of total edible oilseeds (TE2017-18). These crops cover 96.94 percent of area under edible oilseeds as shown in Table 1. 
Table 1. Share of Area and Production of Oilseeds during TE 2017-18

\begin{tabular}{|l|r|r|r|r|}
\hline Oilseeds & \multicolumn{1}{|c|}{ Area (TE 17-18) } & Production(TE17-18) & \multicolumn{1}{|c|}{ Area(Percent) } & Production (Percent) \\
\hline Groundnut & 4940.68 & 7712.28 & 20.26 & 28.49 \\
\hline Sesame & 1732.52 & 795.09 & 24.10 & 2.94 \\
\hline Rapeseed- Mustard & 5932.17 & 7356.56 & 45.26 & 27.17 \\
\hline Soybean & 11038.92 & 10758.82 & 32 & 39.74 \\
\hline Sunflower & 383.80 & 300.89 & 0.48 & 1.11 \\
\hline Safflower & 117.97 & 73.07 & 0.99 & 0.27 \\
\hline Niger & 242.19 & 76.44 & 100.00 & 0.28 \\
\hline Total Edible Oilseeds & 24388.26 & 27073.15 & & 100.00 \\
\hline
\end{tabular}

Source: Authors' calculation

The study therefore, is restricted only to four oilseed crops, namely, groundnut, rapeseed-mustard, sesame, and soybean. Hence the major producing states of these crops have been taken into account for the sake of analysis. The state wise percentage share of area and production of different oilseeds is presented in table 2. Andhra Pradesh, Gujarat, Karnataka, Madhya Pradesh, Maharashtra.

Table 2. Crop-wise Major oilseeds producing states in India during TE 2017-18

\begin{tabular}{|c|c|l|c|c|}
\hline $\begin{array}{c}\text { Sl. } \\
\text { No }\end{array}$ & Crops & \multicolumn{1}{|c|}{ States } & \multicolumn{1}{c|}{ Percentage coverage } \\
\cline { 3 - 6 } & Groundnut & $\begin{array}{l}\text { Andhra Pradesh (17.02, 10.46), Gujarat (32.74, 40.23), Karnataka(8.72, 3.70), } \\
\text { Madhya Pradesh (4.82, 4.51) Maharashtra (4.72, 3.32), Rajasthan(11.56, 14.71) } \\
\text { and Tamil Nadu (6.45, 10.61) }\end{array}$ & 86.03 & 87.55 \\
\hline 1 & $\begin{array}{l}\text { Rapeseed- } \\
\text { Mustard }\end{array}$ & $\begin{array}{l}\text { Gujarat (3.44, 4.53), Haryana (8.79, 12.35), Madhya Pradesh (11.65, 11.07), } \\
\text { Rajasthan (41.06, 45.13)Uttar Pradesh (11.02, 10.40) and West Bengal (8.61, } \\
7.42)\end{array}$ & 84.56 & 90.90 \\
\hline 3 & Sesame & $\begin{array}{l}\text { Gujarat (8.41,9.13), Madhya Pradesh (22.49, 22.60), Rajasthan(17.04,11.72), } \\
\text { Uttar Pradesh (22.98,13.91) and } \\
\text { West Bengal (13.49,28.04) }\end{array}$ & 84.40 \\
\hline 4 & Soybean & $\begin{array}{l}\text { Madhya Pradesh(53.15, 55.28), Maharashtra (36.60, 34.24) and Rajasthan } \\
(10.25,10.48)\end{array}$ & 100 & 100 \\
\hline
\end{tabular}

Source: Authors' calculation

Rajasthan and Tamil Nadu have been selected to analyze groundnut production. These states produce 87.55 percent of groundnut and allocate 86.03 percent area to groundnut. The state of Gujarat, Haryana, Madhya Pradesh, Rajasthan, Uttar Pradesh, and West Bengal have been considered for rapeseed- mustard. These states produce 90.90 percent of rapeseed-mustard allocating 84.56 percent area to it. Gujarat, Madhya Pradesh, Rajasthan, Uttar Pradesh, and West Bengal are the major sesame producing state using 84.40 percent area for sesame production with 85.40 percent of sesame output. The study considers the above mentioned states for analyzing sesame. The states Madhya Pradesh and Maharashtra have been selected for soybean. These states produce 89.52 percent soybean allocating 89.75 percent area to it.

\subsection{Selection of Time}

The study covered a time span from 1976-77 to 2017-18 for groundnut, rapeseed-mustard, and sesame. The soybean has been analyzed during 1997-98 to 2017-18. The year 1976-77 is chosen as the base year because the scenario of the Indian oilseeds economy has changed significantly since the late 70s. During this period, India became a net importer of oilseeds from the exporter. There are two structural break-through in the oilseeds sector. The first one is in 1986 and the other is in 1994. In 1986, Technology Mission on Oilseeds was established for self-sufficiency in oilseeds production whereas in 1994, opening up the edible oils sector as a part of economic reform.

\subsection{Data Sources}

For the selected states, time series data related to area, yield, farm harvest prices of edible oilseeds and their competing crops $^{\mathrm{i}}$, irrigation and rainfall have been used during the period of 1976-77 to 2017-18. This data is collected from secondary sources published by Directorate of Economics and Statistics, Ministry of Agriculture and farmers Welfare, Govt. of India. 


\section{Research Methodology}

\subsection{Econometric Model}

The basic acreage allocation model which has come to be called as Nerlovian price expectation model is as follows:

$$
A^{*}=b_{0}+b_{1} P{ }_{t}+b_{2} Y^{*}+b_{3} Z^{*}+U_{t}
$$

Desire acreage under the crops in current time period $\left(A_{t}^{*}\right)$ is determined by the price expected in the current time period $\left(P_{t}^{*}\right)$, expected yield in the current period $\left(Y_{t}^{*}\right)$, expected weather and others variables in current time period $\left(Z_{t}^{*}\right), b_{0}, b_{1}, b_{2}$, and $b_{3}$, are the parameters to be estimated and $U_{t}$ is the error term and assumed to be distributed normally with zero mean and constant variance $\sigma^{2}$

$$
\left(P_{t}^{*}-P_{t-1}^{*}\right)=\beta\left(P_{t-1}-P^{*}{ }_{t-1}\right)
$$

$0<\beta<1$

Where;

$\mathrm{P}_{\mathrm{t}}=$ expected price of the crops in year $\mathrm{t}$

$\mathrm{P}_{\mathrm{t}-1}=$ expected price of the crops in year $\mathrm{t}-1$

$\mathrm{P}_{\mathrm{t}-1}=$ actual price of the crops in year $\mathrm{t}-1$

$\beta=$ the coefficient of price expectation, and;

The hypothesis described through equation (2) is price expectation hypothesis. The expression on the left-hand side of this equation is the revision in price expectation from year to year. On the right-hand side, the expression is the error made by the farmers in predicting the price during $t-1$. The coefficient of price expectation $(\beta)$ indicates that only a fraction of last year's error in price prediction is translated into revision in expected price during the current year.

Nerlovian lagged adjustment model postulates that the actual acreage under a crop in each period is adjusted in a proportion to the difference between the desired acreage in the long run equilibrium and the actual acreage under it in the preceding year.

$$
\begin{gathered}
\quad A_{t}-A_{t-1}=\gamma\left(A_{t}^{*}-A_{t-1}\right) ; \\
\text { Therefore, } A_{t}=\gamma A_{t}^{*}+(1-\gamma) A_{t-1}
\end{gathered}
$$

We used the following finalized model for determining the acreage response to various factors that are lagged price, lagged area, lagged yield, lagged price of competitive crop, lagged yield of competitive crop, lagged irrigation, lagged average rain fall and technological support. According to Nerlove (1956) model farmer's behavior in its simplest form is given below (i.e., applied form of equation 1 ):

$$
\begin{gathered}
A_{t}=\gamma b_{0}+\gamma b_{1} P_{t-1}+\gamma b_{2} P_{t-1}^{c}+\gamma b_{3} Y_{t-1}+\gamma b_{4} Y_{t-1}^{c}+\gamma b_{7} R_{t-1}+\gamma b_{8} I_{t-1}+\gamma b_{9} T_{t}+\gamma b_{10} D_{t}+(1-\gamma) A_{t-1}+\gamma U_{t} \\
A_{t}=C_{0}+C_{1} P_{t-1}+C_{2} P_{t-1}^{c}+C_{3} Y_{t-1}+C_{4} Y_{t-1}^{c}+C_{5} R_{t-1}+C_{5} I_{t-1}+C_{7} D_{1}+C_{8} D_{2}+C_{9} A_{t-1}+V_{t} \ldots
\end{gathered}
$$

In the double $\log$ form, this model would be as following:

$$
\ln A_{t}=\ln C_{0}+\ln C_{1} P_{t-1}+\ln C_{2} P_{t-1}^{c}+\ln C_{3} Y_{t-1}+\ln C_{4} Y_{t-1}^{c}+\ln C_{5} R_{t-1}+\ln C_{6} I_{t-1}+\ln C_{7} T_{t}+\ln C_{8} D_{t}+\ln C_{9} A_{t-1}+V_{t}
$$

Where;

$\mathrm{A}_{\mathrm{t}} \quad=$ Area of oilseeds crop in the current year (hectare)

$\mathrm{A}_{\mathrm{t}-1}=$ area of concerned oilseeds crop lagged by one year (hectare)

$\mathrm{P}_{\mathrm{t}-1}=$ Farm harvest price of oilseeds crop lagged by one year (Rs/qtl.)

$\mathrm{P}_{\mathrm{t}-1}^{\mathrm{c}}=$ Farm harvest price of competing crop lagged by one year (Rs/qtl.)

$\mathrm{Y}_{\mathrm{t}-1}=$ Yield of oilseeds crop lagged by one year $(\mathrm{kgs} / \mathrm{ha})$

$\mathrm{Y}_{\mathrm{t}-1}^{\mathrm{c}}=$ Yield of the competing crop lagged by one year ( $\left.\mathrm{kgs} / \mathrm{ha}\right)$

$\mathrm{R}_{\mathrm{t}-1}=$ Rainfall during monsoon period in current year $(\mathrm{mm})$

$\mathrm{I}_{\mathrm{t}-1}=$ Irrigated area of oilseeds crop in current year (hectare)

$\mathrm{T}_{\mathrm{t}} \quad=$ Technology (Dummy used for 'TMO')

$\mathrm{D}_{\mathrm{t}}=$ Policy making Variable (Dummy used for 'economic liberalization')

$\mathrm{V}_{\mathrm{t}}=\mathrm{a}$ disturbance term

$\gamma$ is the acreage adjustment coefficient 


\subsection{Empirical Model}

The panel data has been used to estimate the acreage response model in this study. Since it has been examined that unit root is present in the panel at level, the application of fixed effect and a random effect regression models are not suitable in this case. It is here where the use of advanced econometric methodologies becomes relevant. For this particular case, the suitable techniques are the general co-integration methodology and Error Correction Model (ECM). The ECM allows examining the existence of long-run and short-run relationships among variables. All the used variables are stationary and so the results are consistent (Tripathi, A., \& Prasad, A. R. 2009). This study has used panel data along with a time-lagged dependent variable included as a regressor. So panel is dynamic. In this panel cross section variables are less than time, therefore panel is heterogeneous (large and small $\mathrm{N}$, large $\mathrm{T}$ and $\mathrm{N}<\mathrm{T}$ ). Therefore, the study applied Heterogeneous Dynamic panel model also known as ARDL model. An ARDL model is also known as an Autoregressive Dynamic Lag model. Auto regressive means that the model includes lags of the dependent variable as explanatory variables. The Dynamic Lag implies that the model also includes lags of the explanatory variables.

Setting this out more precisely, the unrestricted specification for the ARDL system of equations is

$$
Y_{i t}=\sum \delta_{i} Y_{i t-1}+\sum \beta_{i j}^{\prime} X_{I t-1}+\varphi_{i}+e_{i t}
$$

Where $Y i_{t} i$ is dependent variable, $X_{i t}$ is a ( $\left.k x l\right)$ vector of explanatory variables for group $i$ that are allowed to be purely $I(0)$ or I(l) or cointegrated, $\delta_{i}$ is the coefficient of dependent variable called scalar, $\beta^{\prime}{ }_{i j}$ are (kxl) coefficients vector,$\varphi_{i}$ is unit specific fixed effect, $e_{i t}$ is the error term. $i=1,2, \ldots \ldots . N, t=1,2 \ldots \ldots ., \quad p, q$ are optimal lag order.

The re-parameterized ARDL $(p, q,, \ldots . q)$ error correction model is specified as

$$
\Delta Y_{i t}=\theta i\left(Y_{i t-1}-\lambda_{i}^{\prime} X_{i t-1}\right)+\Delta \sum \xi_{i j} Y_{i t-1}+\Delta \sum \gamma^{\prime} X_{i t}+\varphi_{i}+e_{i t} \quad \ldots \ldots
$$

$\left(Y_{i t-1}-\lambda_{i}{ }^{\prime} X_{i t}\right)$ is the error correction term, $\theta_{i}=-\left(1-\delta_{i j}\right)$ group specific speed of adjustment coefficient, $\lambda_{i}{ }^{\prime}$ is vector of long run relationship, $\gamma^{\prime}, \xi$ are short run dynamic coefficients.

To estimate the model, the study uses both Mean Group (MG) and Pooled Mean Group (PMG) methods. The MG estimator (Pesaran \& Smith 1995) relies on estimating N time-series regressions and averaging the coefficients, whereas the PMG estimator (Pesaran et al., 1997, 1999) relies on a combination of pooling and averaging of coefficients

In case of the MG model, in order to resolve the bias due to heterogeneous slopes in dynamic panels, the MG estimator also provides the long-run parameters for the panel through making an average of the long-run parameters from ARDL models for individual cross section. On the other hand, the Pool Mean Group was applied in order to detect the long and short run association between dependent variable and regressors, and to also investigate the possibly heterogeneous dynamic issue across cross section. In PMG estimation, only the long-run coefficients are constrained to be the same across countries, while the short-run coefficients are allowed to vary. The appropriate technique to be used to the analysis of dynamic panels is Autoregressive distributed lag ARDL (p, q) model in the error correction form and then estimate the model based on the MG and the PMG estimators.

In this article, we compare the MG and PMG estimation results. Hausman test can be used to test whether there is a significant difference between the PMG and MG. The null hypothesis of this test is that the PMG is more efficient. If the null is not rejected, then we use the PMG estimator since it is efficient.

The base model between area of oilseeds crop and its determinant factors as $A R D L(1,1,1, \ldots . .1)$

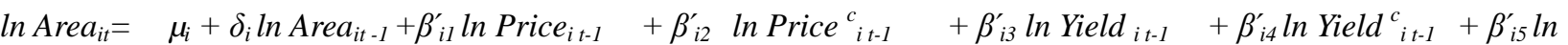

$$
\begin{aligned}
& \text { Irrigation }_{i t-1} \quad+\beta_{i 6}^{\prime} \text { ln Rainfall } \text { It }-1_{1}+\beta_{i 7}^{\prime} \text { In Technology }{ }_{i t-1}+\varepsilon_{i t} \quad \ldots \ldots \ldots . . .(10)
\end{aligned}
$$

Through the transformation of this equation, the short-run model between acreage allocation and its determinant is as follows:

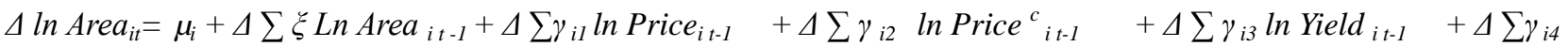

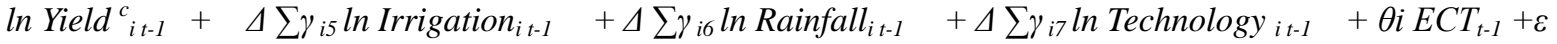

$$
\begin{aligned}
& \text { it }
\end{aligned}
$$

$\triangle$ indicate $1^{\text {st }}$ difference and $\theta_{i}=-\left(1-\delta_{i}\right)$ is the co-efficient of error correction, when $\theta_{i}$ is significant and negative it implies that co-integration is exist.

According to (Banerjee et. al., 1998), the error correction term indicates the speed adjustment to restore equilibrium in the dynamic model. The error correction coefficient shows how quickly variables converge/diverge to equilibrium and it should have a statically significant coefficient with a negative/positive sign. The highly significant Error Correction Term further confirms the existence of a stable long-run relationship. 


\section{Results and Discussion}

\subsection{Descriptive Statistics}

The descriptive statistics (Mean, Standard Deviation, Min and Max) of groundnut, rapeseed-mustard and sesame panel data are presented in Appendix table 1. In case of soybean, the states of Madhya Pradesh and Maharashtra cover more than 90 percent area. Therefore the construction panel data of acreage allocation to soybean is irrelevant. The study has considered Madhya Pradesh only one state as it allocates more than 50 percent area to soybean. The descriptive statistics of soybean acreage allocation of Madhya Pradesh is also presented in this Table.

\subsection{Analysis of Empirical Results}

The area allocated to major oilseeds shows constant (rapeseed-mustard) or declining (groundnut and sesame) trends since liberalization. The study has tried to find the factors (price and non-price factors) influencing the acreage allocated to major oilseed crops using ARDL model. The ARDL model can be applied if all the variables are I $(0)$ or I(1) or a mix of the two. However, it should be noted that it cannot be used when the variables are either I(2) or higher than that. To ensure this, the study first employs two different types of panel unit root tests, namely Im, Pesaran and Shin and Levin Lin Chu tests, in order to determine the order of integration between all the series in the dataset. According to Pesaran and Smith (1995); Pesaran et al. (1997); Pesaran et. al. (1999), the order of integration of the variables is not essential for applying ARDL model as long as the variables of interest are $\mathrm{I}(0)$ and $\mathrm{I}(1)$. The study uses unit root tests to make sure that no series exceeds the integration of order I(1).

\subsubsection{Results of Unit Root Test}

The results of the unit-root test of groundnut, rapeseed- mustard, and sesame panel are presented in table 3. The Im, Pesaran and Shin and Levin Lin Chu tests are used to identify the panel data unit root. The results indicate that in case of groundnut, the yield of groundnut, irrigation, rainfall, and rainfall fluctuation panel is stationary at level i.e., $\mathrm{I}(0)$, meaning no unit roots are present at level.

Table 3. Results of Unit Root Test of Groundnut, Rapeseed-Mustard and Sesame

\begin{tabular}{|c|c|c|c|c|c|c|c|c|}
\hline & \multicolumn{4}{|c|}{ Level } & \multicolumn{4}{|c|}{$1^{\text {st }}$ Difference } \\
\hline & \multicolumn{2}{|c|}{ Im-Pesaran-Shin } & \multicolumn{2}{|c|}{ Levin -Lin -Chu } & \multicolumn{2}{|c|}{ Im-Pesaran-Shin } & \multicolumn{2}{|c|}{ Levin -Lin -Chu } \\
\hline Variables & Statistics & P Value & Statistics & P Value & Statistics & P Value & Statistics & P Value \\
\hline & \multicolumn{8}{|c|}{ Groundnut Panel } \\
\hline Groundnut Area & 1.256 & 0.896 & 0.950 & 0.830 & -12.574 & 0.000 & -10.473 & 0.000 \\
\hline Groundnut Price & 2.210 & 0.986 & -1.583 & 0.057 & -15.075 & 0.000 & -13.177 & 0.000 \\
\hline Groundnut Yield & -2.928 & 0.002 & -2.437 & 0.007 & -16.924 & 0.000 & -13.356 & 0.000 \\
\hline Competitive Crop Price & 3.032 & 0.999 & -0.029 & 0.489 & -14.139 & 0.000 & -11.280 & 0.000 \\
\hline Competitive Crop Yield & -0.136 & 0.446 & -1.076 & 0.141 & -13.590 & 0.000 & -10.519 & 0.000 \\
\hline Irrigation & -5.054 & 0.000 & -6.169 & 0.000 & -10.561 & 0.000 & -7.853 & 0.000 \\
\hline Rainfall & -6.289 & 0.000 & -5.117 & 0.000 & -15.713 & 0.000 & -11.427 & 0.000 \\
\hline Rainfall Fluctuation & -6.510 & 0.000 & -5.893 & 0.000 & -15.919 & 0.000 & -15.449 & 0.000 \\
\hline TMO Effect & -0.674 & 0.250 & -0.494 & 0.006 & -8.561 & 0.000 & -8.155 & 0.000 \\
\hline \multirow[t]{2}{*}{ Liberalization Effect } & 1.619 & 0.947 & -0.396 & 0.346 & -8.561 & 0.000 & -8.155 & 0.000 \\
\hline & \multicolumn{8}{|c|}{ Rapeseed-Mustard Panel } \\
\hline Rapeseed-Mustard Area & 0.430 & 0.666 & -1.676 & 0.047 & -8.793 & 0.000 & -7.073 & 0.000 \\
\hline Rapeseed-Mustard Price & 2.221 & 0.987 & 1.068 & 0.143 & -17.096 & 0.000 & -12.830 & 0.000 \\
\hline Competitive Crop Price & 3.196 & 0.999 & -0.248 & 0.402 & -12.589 & 0.000 & -11.070 & 0.000 \\
\hline Rapeseed-Mustard Yield & -1.107 & 0.134 & -3.193 & 0.001 & -15.344 & 0.000 & -12.407 & 0.000 \\
\hline Competitive Crop Yield & -2.234 & 0.013 & -3.835 & 0.000 & -16.480 & 0.000 & -14.057 & 0.000 \\
\hline Irrigation & -3.242 & 0.001 & -5.081 & 0.000 & -11.157 & 0.000 & -10.421 & 0.000 \\
\hline TMO Effect & -0.624 & 0.266 & -2.309 & 0.011 & -7.926 & 0.000 & -7.550 & 0.000 \\
\hline \multirow[t]{2}{*}{ Liberalization Effect } & 1.499 & 0.933 & -0.367 & 0.357 & -7.926 & 0.000 & -7.550 & 0.000 \\
\hline & \multicolumn{8}{|c|}{ Sesame Panel } \\
\hline Sesame Area & 0.648 & 0.258 & -0.283 & 0.389 & -8.786 & 0.000 & -7.747 & 0.000 \\
\hline Sesame Price & 1.683 & 0.954 & -1.402 & 0.080 & -13.567 & 0.000 & -11.945 & 0.000 \\
\hline Competitive Crop Price & 2.143 & 0.984 & -0.904 & 0.183 & -12.135 & 0.000 & -10.673 & 0.000 \\
\hline Sesame Yield & -2.154 & 0.016 & -2.415 & 0.008 & -12.681 & 0.000 & -11.424 & 0.000 \\
\hline Competitive Crop Yield & 0.518 & 0.698 & -0.283 & 0.389 & -14.863 & 0.000 & -12.313 & 0.000 \\
\hline Rainfall & -6.040 & 0.000 & -4.720 & 0.000 & -14.378 & 0.000 & -10.778 & 0.000 \\
\hline TMO Effect & -0.570 & 0.285 & -2.108 & 0.018 & -7.235 & 0.000 & -6.892 & 0.000 \\
\hline Liberalization Effect & 1.368 & 0.914 & -0.335 & 0.369 & -7.235 & 0.000 & -6.892 & 0.000 \\
\hline
\end{tabular}

Source: Authors' calculation 
However, other panels have a unit root present at the level. This implies that the series is non-stationary at the level. It becomes stationary at the 1st difference i.e, I(1). These results show the existence of a mixed level of integration and also indicate that all panels are stationary at the 1st difference in both the methods. Hence, no unit roots are present in the panels considered at 1 st difference.

The results of the unit root test of rapeseed-mustard have also been presented in table 3 . The panel of competitive crop yield and irrigation has no unit root at level. They are stationary at level, i.e. I(0). The remaining panel of rapeseed-mustard has a unit root at level. These variables are non-stationary at level but are stationary at 1st difference, i.e., I(1). At 1st difference, no series has a unit root. Hence all the series are stationary at 1st difference in both the methods. The results indicate that a mixed level of integration is also present for rapeseed-mustard as well.

From table 3, it can be said that the panel of rainfall and sesame yield have no unit root at level implying that the panels are stationary at level i.e., I(0). Other panels have unit root at level. Therefore, all the panel of sesame are non stationary at level excepting rainfall and sesame yield. At $1^{\text {st }}$ difference all panels have been observed to have no unit root. Hence, all the panels are stationary at $1^{\text {st }}$ difference. A mixed integration is also seen to exist in sesame panel data.

Due to the presence of mixed levels of integration among series (panel) of groundnut, rapeseed-mustard and sesame, the study proceeds to apply the Panel ARDL technique to test the long-run relationship among variables instead of traditional static or panel co-integration test (Asteriou and Monastiriotis, 2004). The coefficient of the error correction term must be negative and significant in order to arrive at any valid conclusion regarding the long-run equilibrium relationship between variables and the speed of adjustment if there is any deviation from equilibrium.

\subsubsection{Results of Panel ARDL}

The results of panel ARDL estimation of groundnut, rapeseed-mustard and sesame, using both PMG and MG methods are presented in Table 4, Table 5 and Table 6 respectively. The study applies the Hausman test to distinguish between the PMG and MG estimation methods. This will help to determine the long-run settings most suitable for the panel data used in this study. The Hausman test shows that the PMG estimation method is more suitable than the MG estimation method for groundnut, rapeseed-mustard and sesame. The results of the Hausman test are also presented in Table 4, Table 5 and Table 6.

Since Madhya Pradesh has only been taken into account as the soybean cultivating state, the panel could not have been constructed here. Hence the Simple ARDL model has been applied for soybean instead of panel ARDL model. The results of unit root test $(A D F)$ for soybean are presented in table 7 while the results of the ARDL model are shown in table 8 .

Groundnut: The short-run, long-run and error correction results of groundnut are presented in table 4 . The chi ${ }^{2}$ value of the Hausman test is 0.57 with 0.99 probability. Therefore the analysis is restricted only on PMG results. The PMG estimator constrains the long-run elasticities to be equal across all panels.

Among the co-integrated panel of groundnut, the price of competitive crops, rainfall and TMO have significant effect on area allocated to groundnut in the long run. The coefficient of price of competitive crops has a negative sign and is significant which is consistent with the standard production theory. Since the price has moved in favour of competitive crops of groundnut, there has been an increase in the area allocated to competitive crops. Table 4 explains that with the rise in price of competitive crops by 1 percent, farmers shift 58 percent of cultivated area from groundnut to its competitive crop in the long run.

Table 4. Estimation of Panel ARDL Model for Groundnut Area Allocation

\begin{tabular}{|c|c|c|c|c|c|c|}
\hline$\Delta$ Groundnut Area & \multicolumn{3}{|c|}{ Pooled Mean Group } & \multicolumn{3}{|c|}{ Mean Group } \\
\hline \multicolumn{7}{|c|}{ Short Run } \\
\hline Variables & Coefficients & $\mathrm{Z}$ & $\mathrm{P}>|\mathrm{Z}|$ & Coefficients & $\mathrm{Z}$ & $\mathrm{P}>|\mathrm{Z}|$ \\
\hline ECT & -0.148 & -3.45 & 0.001 & -0.591 & -5.92 & 0.000 \\
\hline$\Delta$ Groundnut Price & 0.035 & 0.50 & 0.616 & 0.065 & 0.98 & 0.326 \\
\hline$\Delta$ Competitive Crop Price & 0.006 & 0.12 & 0.908 & -0.018 & -0.34 & 0.736 \\
\hline$\Delta$ Irrigation & 0.048 & 1.16 & 0.245 & 0.027 & 1.54 & 0.124 \\
\hline$\Delta$ Rainfall & 0.075 & 2.64 & 0.008 & 0.047 & 0.79 & 0.431 \\
\hline$\Delta \quad$ Rainfall Fluctuation & 0.011 & 0.57 & 0.569 & 0.002 & 0.19 & 0.849 \\
\hline$\Delta$ TMO Effect & -0.068 & -0.54 & 0.589 & -0.124 & -1.20 & 0.229 \\
\hline$\Delta$ Liberalization Effect & 0.007 & 0.18 & 0.859 & 0.055 & 1.33 & 0.185 \\
\hline Constant & 2.439 & 3.60 & 0.000 & 4.778 & 4.64 & 0.000 \\
\hline \multicolumn{7}{|c|}{ Long Run } \\
\hline Groundnut Price & 0.077 & 0.36 & 0.717 & -0.010 & -0.05 & 0.964 \\
\hline Competitive Crop Price & -0.583 & -2.54 & 0.011 & -0.114 & -0.95 & 0.345 \\
\hline
\end{tabular}




\begin{tabular}{|l|r|r|r|r|r|r|}
\hline Irrigation & -0.046 & -0.61 & 0.539 & 0.080 & 0.45 & 0.651 \\
\hline Rainfall & -1.244 & -3.23 & 0.001 & -0.270 & -2.15 & 0.032 \\
\hline Rainfall Fluctuation & -0.009 & -0.17 & 0.869 & -0.017 & -0.48 & 0.628 \\
\hline TMO Effect & 0.454 & 3.38 & 0.001 & 0.301 & 2.67 & 0.008 \\
\hline Liberalization Effect & -0.139 & -1.13 & 0.260 & -0.157 & -2.68 & 0.007 \\
\hline Hausman Test (Chi $^{2}$ ) & \multicolumn{3}{|c|}{0.57} & & Prob > Chi & \\
\hline
\end{tabular}

Source: Authors' calculation

Basically groundnut is a kharif crop in India. The area allocation mostly depends on rainfall. In this analysis the sign of coefficient of rainfall is negative, which means excessive rainfall has reduced the area allocated to groundnut. The technological change through TMO has positive and significant effect on area under groundnut. However, this effect got exhausted within a short span of time. The Economic Liberalization has a negative effect on groundnut area allocation which is not statistically significant in PMG method (but it is significant in MG method). Other variables have no significant effect on area allocation of groundnut in the long run.

However, in the short run only rainfall has significant and positive effect on rainfall. It implies that good rainfall in kharif season of last year influences the area allocation of groundnut in current year. Other factors have no significant impact on groundnut area allocation during the short run. The coefficient of error correction term is negative and significant. The magnitude of coefficient is -0.148 . Therefore, speed of adjustment towards long run equilibrium is 14.8 percent every year, implying that a stable long-run relationship exists.

Rapeseed Mustard: The results of the panel ARDL of rapeseed-mustard are presented in table 5. The chi 2 value of the Hausman test is 1.76 with a probability 0.97 percent indicates the study cannot reject the null hypothesis (H0: PMG is an accepted, model).

Table 5. Estimation of Panel ARDL Model for Rapeseed-Mustard Area Allocation

\begin{tabular}{|c|c|c|c|c|c|c|}
\hline \multirow{2}{*}{$\Delta$ Rapeseed-Mustard Area } & \multicolumn{3}{|c|}{ Pooled Mean Group } & \multicolumn{3}{|c|}{ Mean Group } \\
\hline & \multicolumn{6}{|c|}{ Short Run } \\
\hline Variables & Coefficients & $\mathrm{Z}$ & $P>|Z|$ & Coefficients & $\mathrm{Z}$ & $P>|Z|$ \\
\hline ECT & -0.305 & -3.74 & 0.000 & -0.572 & -4.86 & 0.000 \\
\hline$\Delta \quad$ Rapeseed-Mustard Price & 0.232 & 2.75 & 0.006 & 0.159 & 4.35 & 0.000 \\
\hline$\Delta$ Competitive Crop Price & -0.083 & -0.62 & 0.535 & 0.048 & 0.87 & 0.385 \\
\hline$\Delta \quad$ Rapeseed-Mustard Yield & 0.133 & 0.90 & 0.368 & -0.088 & -1.76 & 0.078 \\
\hline$\Delta$ Competitive Crop Yield & -0.169 & -2.52 & 0.012 & -0.094 & -0.51 & 0.608 \\
\hline$\Delta$ Irrigation & 0.066 & 1.04 & 0.298 & -0.062 & -1.11 & 0.265 \\
\hline$\Delta$ TMO Effect & -0.069 & -1.02 & 0.306 & 0.055 & -1.10 & 0.271 \\
\hline$\Delta$ Liberalization Effect & 0.054 & 1.29 & 0.198 & 0.062 & 3.70 & 0.000 \\
\hline \multirow[t]{2}{*}{ Constant } & 0.813 & 3.95 & 0.000 & 1.025 & 0.58 & 0.564 \\
\hline & \multicolumn{6}{|c|}{ Long Run } \\
\hline Rapeseed-Mustard Price & 0.256 & 1.08 & 0.278 & 0.450 & 0.90 & 0.367 \\
\hline Competitive Crop Price & -0.192 & -0.93 & 0.354 & -0.526 & -0.89 & 0.372 \\
\hline Rapeseed-Mustard Yield & 0.446 & 2.08 & 0.038 & 0.747 & 2.61 & 0.009 \\
\hline Competitive Crop Yield & -0.198 & -0.57 & 0.569 & -0.651 & -1.01 & 0.311 \\
\hline Irrigation & 0.211 & 2.27 & 0.023 & 0.351 & 3.33 & 0.001 \\
\hline TMO Effect & 0.345 & 2.37 & 0.018 & 0.271 & 2.37 & 0.018 \\
\hline Liberalization Effect & -0.244 & -1.98 & 0.048 & -0.102 & -1.66 & 0.970 \\
\hline Hausman Test $\left(\mathrm{Chi}^{2}\right)$ & \multicolumn{3}{|c|}{1.76} & Prob > $\mathrm{Chi}^{2}$ & \multicolumn{2}{|c|}{0.9778} \\
\hline
\end{tabular}

Source: Authors' calculation

In the long run, the area allocation of rapeseed-mustard in most states has a slightly increasing trend. The results of PMG estimation indicate that the rapeseed- mustard productivity has a significant and positive impact on area allocation. Rapeseed-mustard is one of the important rabi crops in India. Therefore, the area allocation of this crop depends on availability of irrigation. As usual, the coefficient of irrigation is positive and statistically significant. The TMO has a positive and significant effect on area allocation of rapeseed-mustard. The technological changes in the oilseeds sector after establishing TMO affects only groundnut and rapeseed-mustard. So, this coefficient matched with reality. After liberalization, the oilseeds sector suffered and this is coincident with the result i.e., the coefficient of liberalization dummy is significantly negative in the case of rapeseed-mustard area allocation. But interestingly, the price has no significant role on area allocation of rapeseed-mustard in the long-run. 
However, in the short-run the price influences the farmers to allocate an area in favor of rapeseed-mustard. The short-run coefficient of its own price is positive and significant. It means that an increase in the price of rapeseed-mustard has encouraged the farmers to allocate area more and more in favor of rapeseed-mustard. At the same time, the coefficient of price of competitive crops is negative and significant. This indicates that the price of the competitive crop is lower as compared to rapeseed-mustard, which helps the shifting of the area from competitive crop to the rapeseed -mustard in the short-run.

The coefficient of the error correction term is negative and significant. Therefore, co-integration is present among the variables. So a stable long-run relationship exists in the model. The magnitude of the coefficient is -0.305 is statistically significant at 1percent level, suggesting that 30.5 percent of previous year's error is corrected within the current year. Therefore the speed of adjustment towards long-run equilibrium is 30.5 percent every year.

Sesame: Hausman test results among PMG and MG estimation of Sesame placed in table 6 which implies that PMG is the accepted estimation.

The price of sesame has a positive and significant impact on area allocation in the long-run. This is logically true. The increase in the price of sesame influences the farmers' revenue. If the price of sesame goes up, farmers allocate more and more areas in favor of sesame and vice-versa. The effect of TMO and liberalization has gone against the area allocation of sesame during this period. The coefficients of both variables are negative and significant. The relative strength of the negative effect is more than a positive effect on sesame acreage allocation. Therefore, the long-run trend of sesame allocation is downward. Sesame is a pre-Kharif crop; to some extent, it depends on rainfall. Irrigation has no role in sesame cultivation. The study uses both rainfall and irrigation in this model, and both have insignificant effects in the long run. However, rainfall has a positive and significant influence on area allocation in the short-run while other variables have no significant role in the short-run to allocate an area in favor of sesame.

Table 6. Estimation of Panel ARDL Model for Sesame Area Allocation

\begin{tabular}{|c|c|c|c|c|c|c|}
\hline \multirow[t]{2}{*}{$\Delta \quad$ Sesame Area } & \multicolumn{3}{|c|}{ Pooled Mean Group } & \multicolumn{3}{|c|}{ Mean Group } \\
\hline & \multicolumn{6}{|c|}{ Short Run } \\
\hline Variables & Coefficients & $\mathrm{Z}$ & $\mathrm{P}>|\mathrm{Z}|$ & Coefficients & $\mathrm{Z}$ & $\mathrm{P}>|\mathrm{Z}|$ \\
\hline ECT & -0.2186 & -3.16 & 0.002 & -0.4501 & -6.88 & 0.000 \\
\hline$\Delta$ Sesame Price & -0.0643 & -1.05 & 0.293 & 0.0793 & 0.53 & 0.596 \\
\hline$\Delta$ Competitive Crop Price & 0.0150 & 0.15 & 0.883 & 0.0228 & 0.22 & 0.827 \\
\hline$\Delta$ Sesame Yield & -0.0083 & -0.15 & 0.880 & -0.0025 & -0.05 & 0.962 \\
\hline$\Delta$ Competitive Crop Yield & 0.0426 & 0.47 & 0.641 & -0.1176 & -0.61 & 0.543 \\
\hline$\Delta$ Rainfall & 0.0799 & 3.03 & 0.002 & 0.0698 & 0.87 & 0.387 \\
\hline$\Delta$ TMO Effect & 0.0779 & 0.49 & 0.625 & 0.0739 & 0.31 & 0.758 \\
\hline$\Delta$ Liberalization Effect & -0.0730 & -0.86 & 0.392 & -0.0314 & -0.83 & 0.409 \\
\hline \multirow[t]{2}{*}{ Constant } & 1.1711 & 3.02 & 0.003 & 1.4705 & 0.73 & 0.464 \\
\hline & \multicolumn{6}{|c|}{ Long Run } \\
\hline Sesame Price & 0.8272 & 2.78 & 0.005 & 0.1884 & 0.38 & 0.705 \\
\hline Competitive Crop Price & -0.2923 & -1.18 & 0.239 & -0.1115 & -0.34 & 0.735 \\
\hline Sesame Yield & 0.2671 & 1.56 & 0.118 & 0.1476 & 0.47 & 0.641 \\
\hline Competitive Crop Yield & -0.3075 & -1.10 & 0.273 & 0.0867 & 0.13 & 0.900 \\
\hline Rainfall & -0.5233 & -1.29 & 0.197 & -0.2186 & -0.49 & 0.621 \\
\hline TMO Effect & -0.5864 & -2.64 & 0.008 & -0.1698 & -0.45 & 0.651 \\
\hline Liberalization Effect & -0.4533 & -2.07 & 0.039 & -0.1189 & -0.49 & 0.621 \\
\hline Hausman Test $\left(\mathrm{Chi}^{2}\right)$ & \multicolumn{3}{|c|}{5.25} & Prob> $\mathrm{Chi}^{2}$ & \multicolumn{2}{|c|}{0.6300} \\
\hline
\end{tabular}

Source: Authors' calculation

The coefficient of the error correction term is negative and significant. Since error term negative and significant, there is cointegration among variables. Thus, a stable long-run relationship exists. The magnitude of the coefficient is -0.2186 . Therefore the speed of adjustment towards long-run equilibrium is 21.86 percent every year

Soybean: In soybean cultivation, only two states namely Madhya Pradesh and Maharashtra cover more than 90 percent area. Therefore, the panel data analysis of acreage allocation to soybean is an impossible. In order to keep our discussion in a limited frame, the study has considered only the Madhya Pradesh because this state covers more than 50 percent area of soybean cultivation.

To the application of the ARDL model, the initial task is to check the unit root of variables, which indicates the series is stationary at a level or at 1 st difference or mixture of $\mathrm{I}(0)$ and $\mathrm{I}(1)$. The results of the unit root test (ADF) presented in 
table 7 depict that all the series contain both $\mathrm{I}(0)$ and $\mathrm{I}(1)$ stationary. Therefore, the study has applied the ARDL model for soybean in the state of Madhya Pradesh.

Table 7. Results of Unit Root Test of Soyabean in Madhya Pradesh

\begin{tabular}{|c|c|c|c|c|}
\hline & \multicolumn{4}{|c|}{ Augmented Dickey Fuller Test } \\
\hline & \multicolumn{2}{|c|}{ Level } & \multicolumn{2}{|c|}{$1^{\text {st }}$ difference } \\
\hline Variables & Statistics & $\mathrm{P}$ Value $(5 \%)$ & Statistics & P Value (5\%) \\
\hline Soybean Area & -1.187 & -3.00 & -4.420 & -3.00 \\
\hline Soybean Price & -0.680 & -3.00 & -3.950 & -3.00 \\
\hline Competitive Crop Price & 1.000 & -3.00 & -3.755 & -3.00 \\
\hline Soybean Yield & -4.028 & -3.00 & -11.499 & -3.00 \\
\hline Competitive Crop Yield & -1.407 & -3.00 & -5.800 & -3.00 \\
\hline
\end{tabular}

Source: Authors' calculation

The results of the ARDL model estimation presented in table 8. The long-run results imply that the price of soybean and its competitive crop have significant effect on area allocation in the long run. But the productivity of both soybean and its competitive crops have no significant effect on area allocation of soybean. The soybean price has positively influenced on area allocation of soybean whereas its competitive crop price has negative effect. The coefficients of both soybean price and price of its competitive crops have consistent with the standard production theory. The favourable movement of soybean prices, leads to more and more area allocation towards soybean cultivation. On the other hand, in case of unfavorable price movements, it is quite obvious that if this reduces the area allocated, there is a shift to soybean from competitive crop. Soybean is one of the important kharif crop India. Naturally rainfall influences positive but results is not statistically significant in the long run.

Table 8. Estimation of ARDL Model for Soybean Area Allocation in Madhya Pradesh

\begin{tabular}{|c|c|c|c|c|}
\hline$\Delta$ Soybean Area & Coefficients & Std. Err. & $\mathrm{t}$ & $\mathrm{P}>|\mathrm{Z}|$ \\
\hline ECT & -0.406 & 0.1896 & -2.14 & 0.050 \\
\hline & \multicolumn{4}{|c|}{ Short Run } \\
\hline Constant & 2.445 & 1.5024 & 1.63 & 0.126 \\
\hline & \multicolumn{4}{|c|}{ Long Run } \\
\hline Soybean Price & 0.346 & 0.1689 & 2.05 & 0.060 \\
\hline Competitive Crop Price & -0.276 & 0.1337 & -2.07 & 0.058 \\
\hline Soybean $\quad$ Yield & 0.495 & 0.2890 & 1.72 & 0.108 \\
\hline Competitive Crop Yield & -0.211 & 0.2409 & -0.87 & 0.397 \\
\hline Rainfall & -0.147 & 0.0716 & -0.21 & 0.840 \\
\hline
\end{tabular}

Source: Authors' calculation

In this model, none of the co-integrated variables have significant effect on area allocation of soybean in the short run. But the adjustment term -0.406 is statistically significant at the 5 percent level. The speed of adjustment is very high and the previous year's error is corrected within the current year at a convergence speed of 40.6 percent.

The ARDL bounds testing approach used in this article have been developed by Pesaran et al. (2001). The ARDL bound testing is a new approach for co-integration. The test can be performed by using the F-statistics to check the significance of the lagged co-efficient in the unrestricted correction model. The ARDL model can act efficiently for small sample sizes in time series data. (Tursoy, T., \& Faisal, F., 2016).

The bound co-integration test (Table: 9) implies that $F(5.013)$ statistic is more than $\mathrm{I}(1)$ value, even at 1percent level. Therefore, null hypothesis (no co-integration) is rejected. It means that there is co-integration among the variables. Since long-run relationship exists between the variables, the considering model and its results are accepted. 
Table 9. Results of Bound Test of Co-integration in ARDL Model

\begin{tabular}{|l|l|l|l|}
\hline \multicolumn{5}{|l|}{ Pesaron/Shin/ Smith (2001) ARDL Bounds Test } \\
\hline Estimated Model & $\begin{array}{l}\text { Ln Area, Ln Price of Soybean, Ln Price of Competitive crop, Ln Yield of Soybean, Ln Yield of } \\
\text { Soybean, Ln Rainfall }\end{array}$ \\
\hline Optimal Lag length & $(1,0,0,0,0,0)$ & 1 percent \\
\hline F (Bound Test) & 5.013 & 2.5 percent & 3.41 \\
\hline $\mathrm{H}_{0}$ : no levels relationships & 2.96 & 468 \\
\hline Critical values $(0.1-0.01), \quad$ F- statistic, case 3 & 5 percent & \\
\hline Critical Value & 10 percent & 2.62 & \\
\hline Lower Bound I $(0)$ & 2.26 & 3.79 & \\
\hline Upper Bound I(1) & 3.35 & & \\
\hline Accepted if F < critical value for I(0) regressors & \\
\hline Rejected if F critical value for I(1) regressors
\end{tabular}

Source: Authors' calculation

\section{Conclusion}

The oilseeds sector is a major cause of concern for the Indian policymakers since the post-reform period. India is one of the largest importers of edible oils in the world due to stagnation in production of oilseeds coupled with a growing demand for the same. The country imported almost half of its domestic requirement since 1990s. In order to boost export of oilseeds through generating production surplus, the policymakers may attempt structural reform in oilseeds sector, favourable pricing policy for oilseeds, trade and exchange rate policies in favour of this sector, etc. The policymaker, therefore, would require detailed knowledge of the supply response parameters of the oilseed crops.

The study attempts to investigate the dynamic relationship between acreage allocation of oilseeds and price (own price and prices of competitive crops) and also search for the link between area allocation and other non-price factors including productivity, irrigation, rainfall, technology and the impact of economic liberalization. The analysis is limited only to four oilseed crops, namely, groundnut, rapeseed-mustard, sesame, and soybean. The oilseed crops have been selected in terms of their proportional contribution in total edible oilseeds output as well as the percentage of area under cultivation. Groundnut, rapeseed-mustard, soybean, and sesame account for a major share of the output (98.34 percent) of total edible oilseeds (TE 2017-18). These crops cover 96.94 percent of area under the same. Hence the major states producing groundnut, rapeseed-mustard, sesame, and soybean have been taken into account for the sake of analysis.

The dynamic panel data for 1976-77 to 2017-18 have been used in the analysis. The analysis has utilized the autoregressive distributive lag (ARDL) model to explore the relationship between the dependent and the independent variables and their long-run equilibrium relationship. To estimate the model, both PMG (Pooled Mean Group) and MG (Mean group) estimation methods have been used. The Hausman test which has also been conducted indicates that the PMG is an efficient estimator in this study. The error correction terms are negative and significant. The results show strong evidence of area allocation under groundnut, rapeseed-mustard, sesame and soybean and that their determinants are strongly co-integrated in the long-run. The ARDL results indicate that the speed of adjustment towards long-run equilibrium varies from 14.8 (groundnut) to 40.6 (soybean) percent. The empirical results also imply that the prices of oilseeds and those of competitive crops play an important role (positive and negative) in the allocation of area under different oilseed crops. Rainfall has a significant effect on the area allocated to kharif oilseeds while irrigation is the factor that influences area allocated to rabi oilseeds. The economic liberalization has a significantly negative impact on the area allocated to oilseeds in the long-run.

\section{Acknowledgement}

The final flow of this paper would have not reached it's current shape without the inputs from Ms Sarbani Banerjee. The authors are indebted to her for the patient contribution during the final manuscript. Unfortunately the current pandemic caused by COVID 19 took away the opportunity to show her the published paper in person. Her untimely departure to the other world has left a vacuum and she will be missed by us in all our future endeavours.

\section{References}

Asteriou, D., \& Monastiriotis, V. (2004). What do unions do at the large scale? Macro-economic evidence from a panel of OECD countries. Journal of applied economics, 7(1), 27-46. https://doi.org/10.1080/15140326.2004.12040602

Banerjee, A., Dolado, J., \& Mestre, R. (1998). Error-correction mechanism tests for cointegration in a single-equation framework. Journal of time series analysis, 19(3), 267-283. https://doi.org/10.1111/1467-9892.00091

Government of India. (2014). Status Paper on Oilseeds, Directorate of Oilseeds Development, Ministry of Agriculture and Farmers Welfare, GOI, New Delhi. 
Government of India. (2018a). National Mission on Oilseeds and Oil Palm, Department of Agriculture and Cooperation. Ministry of Agriculture and Farmers Welfare, GOI, New Delhi. https://nmoop.gov.in/Introduction.aspx

Government of India. (2018b). Commodity Profile of Edible Oil February-2018, Ministry of Agriculture and Farmers Welfare, GOI, New Delhi.

Govt. of India. (1976-77 to 2017-18). Area Production and Yield, Farm Harvest Price and Land use Statistics,State Level Data, Directorate of Economics and Statistics, Department of Agriculture, Cooperation and farmers Welfare, Ministry of Agriculture and farmers Welfare Govt. of India.

Nerlove, M. (1956). Estimates of the Elasticities of Supply of Selected Agricultural Commodities. Journal of farm Economics, 38(2), 496-509. https://doi.org/10.2307/1234389

Pesaran, M. H., \& Smith, R. (1995). Estimating long-run relationships from dynamic heterogeneous panels. Journal of econometrics, 68(1), 79-113. https://doi.org/10.1016/0304-4076(94)01644-F

Pesaran, M. H., Shin, Y., \& R. P. Smith. (1997). Estimating long-run relationships in dynamic heterogeneous panels. DAE Working Papers Amalgamated Series 9721. https://doi.org/10.1016/0304-4076 (94)01644-F

Pesaran, M. H., Shin, Y., \& Smith, R. J. (2001). Bounds testing approaches to the analysis of level relationships. Journal of applied econometrics, 16(3), 289-326. https://doi.org/10.1002/jae.616

Pesaran, M. H., Shin, Y., \& Smith, R. P. (1999). Pooled mean group estimation of dynamic heterogeneous panels. Journal of the American statistical Association, 94(446), 621-634. https://doi.org/10.1080/01621459.1999.10474156

Sharma, V. P. (2017). Oilseed Production in India. Springer India. https://doi.org/10.1007/978-81-322-3717-4

Tripathi, A., \& Prasad, A. R. (2009). Estimation of agricultural supply response by cointegration approach. The Indian Economic Journal, 57(1), 106-131. https://doi.org/10.1177/0019466220090106

Tursoy, T., \& Faisal, F. (2016). Causality between stock price and GDP in Turkey: an ARDL bounds testing approach. Romanian Statistical Review, 64(4), 3-19.

Yadav, K. (2011). Oilseeds Scenario of India. Retrieved from http://agropedia.iitk.ac.in/content/oilseeds-scenario-india

\section{Appendix}

Table 1. Descriptive Statistics of Different Oilseeds

\begin{tabular}{|c|c|c|c|c|c|}
\hline & Obs. & Mean & Std. Dev. & Min & Max \\
\hline & \multicolumn{5}{|c|}{ Groundnut } \\
\hline Groundnut Area & 294 & 6.530 & 0.775 & 5.081 & 7.816 \\
\hline Groundnut Price & 294 & 6.883 & 0.919 & 4.718 & 8.759 \\
\hline Groundnut Yield & 294 & 6.869 & 0.431 & 4.892 & 7.920 \\
\hline Competitive Crop Price & 294 & 6.752 & 1.014 & 4.433 & 8.530 \\
\hline Competitive Crop Yield & 294 & 5.824 & 0.764 & 4.184 & 7.530 \\
\hline Irrigation & 294 & 4.622 & 1.420 & -0.865 & 7.028 \\
\hline Rainfall & 294 & 5.083 & 0.522 & 3.159 & 6.136 \\
\hline TMO Effect & 294 & 0.500 & 0.501 & 0.000 & 1.000 \\
\hline \multirow[t]{2}{*}{ Liberalization Effect } & 294 & 0.500 & 0.501 & 0.000 & 1.000 \\
\hline & \multicolumn{5}{|c|}{ Rapeseed-Mustard } \\
\hline Rapeseed-Mustard Area & 252 & 6.293 & 0.848 & 4.179 & 8.211 \\
\hline Rapeseed-Mustard Price & 252 & 6.917 & 0.812 & 5.053 & 8.486 \\
\hline Rapeseed-Mustard Yield & 252 & 6.789 & 0.384 & 5.545 & 7.533 \\
\hline Competitive Crop Price & 252 & 6.292 & 0.988 & 4.505 & 8.644 \\
\hline Competitive Crop Yield & 252 & 7.467 & 0.592 & 5.848 & 8.523 \\
\hline Irrigation & 252 & 5.789 & 0.952 & 3.306 & 8.177 \\
\hline TMO Effect & 252 & 0.738 & 0.440 & 0 & 1 \\
\hline \multirow[t]{2}{*}{ Liberalization Effect } & 252 & 0.500 & 0.500 & 0 & 1 \\
\hline & \multicolumn{5}{|c|}{ Sesame } \\
\hline Sesame Area & 210 & 5.407 & 0.565 & 3.508 & 6.675 \\
\hline Sesame Price & 210 & 7.249 & 0.910 & 5.512 & 9.412 \\
\hline Sesame Yield & 210 & 5.578 & 0.806 & 3.021 & 6.901 \\
\hline Competitive Crop Price & 210 & 6.375 & 1.037 & 4.432 & 8.529 \\
\hline Competitive Crop Yield & 210 & 6.685 & 1.012 & 4.184 & 7.938 \\
\hline Rainfall & 210 & 5.212 & 0.548 & 3.700 & 6.587 \\
\hline
\end{tabular}




\begin{tabular}{|l|l|l|l|l|l|l|}
\hline TMO Effect & 210 & 0.738 & 0.440 & 0 & 1 \\
\hline Liberalisation Effect & 210 & 0.500 & 0.501 & 0 & 1 \\
\hline \multicolumn{5}{|c|}{ Soybean } \\
\hline Soybean Area & 21 & 8.503 & 0.130 & 8.334 & 8.749 \\
\hline Soybean Price & 21 & 7.365 & 0.532 & 6.686 & 8.188 \\
\hline Soybean Yield & 21 & 6.912 & 0.177 & 6.458 & 7.165 \\
\hline Competitive Crop Price & 21 & 6.543 & 0.451 & 6.046 & 7.516 \\
\hline Competitive Crop Yield & 21 & 7.333 & 0.246 & 6.883 & 7.864 \\
\hline Rainfall & 21 & 5.166 & 0.351 & 4.708 & 5.786 \\
\hline
\end{tabular}

Table 2. Oilseeds -wise Competitive Crops in major Oilseeds Producing States

\begin{tabular}{|c|c|c|c|c|c|}
\hline \multicolumn{2}{|c|}{ Groundnut } & \multicolumn{2}{|c|}{ Rapeseed-Mustard } & \multicolumn{2}{|c|}{ Sesame } \\
\hline States & Competitive Crops & States & Competitive Crops & States & Competitive Crops \\
\hline Andhra Pradesh & Cotton & Gujarat & Wheat & Gujarat & Groundnut \\
\hline Gujarat & Cotton & Haryana & Wheat & Madhya Pradesh & Cotton \\
\hline Karnataka & Cotton & Madhya Pradesh & Gram & Rajasthan & Maize \\
\hline Madhya Pradesh & Cotton & Rajasthan & Wheat & Uttar Pradesh & Bajra \\
\hline Maharashtra & Bajra & Uttar Pradesh & Wheat & West Bengal & Jute \\
\hline Rajasthan & Maize & West Bengal & Gram & Soybean & \\
\hline Tamil Nadu & Cotton & & & Madhya Pradesh & Maize \\
\hline
\end{tabular}

${ }^{i}$ Competitive Crops of Different Oilseeds: The state-wise competitive crops of groundnut, rapeseed-mustard, sesame, and soybean are presented in the appendix table2. The groundnut sesame and soybean are mainly Kharif crops in India. Cotton, maize, bajra, and jute are considered as crops competitive to groundnut, sesame, and soybean in the states that produce these crops. On the other hand, rapeseed-mustard is a Rabi crop and therefore competitive to other Rabi crops such as wheat and gram.

\section{Copyrights}

Copyright for this article is retained by the author(s), with first publication rights granted to the journal.

This is an open-access article distributed under the terms and conditions of the Creative Commons Attribution license which permits unrestricted use, distribution, and reproduction in any medium, provided the original work is properly cited. 